Check for updates

Cite this: RSC Adv., 2019, 9, 16554

Received 9th April 2019

Accepted 14th May 2019

DOI: $10.1039 / c 9 r a 02655 j$

rsc.li/rsc-advances

\title{
Influence of the substituent D/A at the 1,2,3- triazole ring on novel terpyridine derivatives: synthesis and properties $\uparrow$
}

\author{
Dawid Zych, (DD *a Aneta Slodek, (D) a Dżastin Zimny, ${ }^{\text {a }}$ Sylwia Golba, ${ }^{\text {b Katarzyna Malarz }}{ }^{\mathrm{c}}$ \\ and Anna Mrozek-Wilczkiewicz ${ }^{c}$
}

\begin{abstract}
In this study, we newly designed and developed a synthesis route based on the 1,3-dipolar cycloaddition of

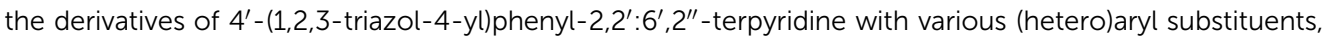
differing in electronic character, on a triazol ring. The obtained compounds were comprehensively characterized by UV-Vis spectroscopy and electrochemical and thermal studies. Moreover, preliminary biological tests were conducted. The investigation allowed the selection of materials with the most promising properties with particular emphasis on the nature of the substituents. In addition, theoretical studies (DFT and TD-DFT) were performed to verify the comprehensive understanding of experimental results.
\end{abstract}

\section{Introduction}

$2,2^{\prime}: 6^{\prime}, 2^{\prime \prime}$-Terpyridine (TPY) derivatives functionalized at different positions have attracted special interest of scientists due to their interesting photophysical properties. ${ }^{1,2}$ They have become frequently used units in material chemistry research related to organic electronics, ${ }^{3-5}$ medicine,,${ }^{6,7}$ catalysis, ${ }^{8}$ and optoelectronics, ${ }^{9-12}$ as evidenced by a number of scientific studies conducted in this field. As a continuation of our previous studies, herein, we decided to combine a terpyridine motif with (4-substituted)-1,2,3-triazol-1-yl ring at the position 4 of the phenyl group of $4^{\prime}$-phenyl-2,2': $: 6^{\prime}, 2^{\prime \prime}$-terpyridine and check the influence of substituents, i.e. (hetero)aryl groups, on the properties of target molecules (Fig. 1).

Molecules containing the 1,2,3-triazole motif substituted at various positions have been of significant interest due to their biological properties such as antituberculosis, ${ }^{13}$ antibacterial ${ }^{14}$ and antioxidative ${ }^{15}$ activities; moreover, another discovery is their ability to image cell structures due to their intense and selective fluorescence in the presence of transition metal compounds ${ }^{16}$ and detect ions of these metals in trace amounts. ${ }^{17}$ The interest of that kind of structure is also strongly connected with the discovery of the $\mathrm{Cu}(\mathrm{I})$-catalyzed 1,3-dipolar

anstitute of Chemistry, Faculty of Mathematics, Physics and Chemistry, University of Silesia, Szkolna 9, 40-007 Katowice, Poland. E-mail: dawidzych92@gmail.com

${ }^{b}$ Institute of Materials Science, University of Silesia, 75 Pulku Piechoty 1A, 41-500 Chorzów, Poland

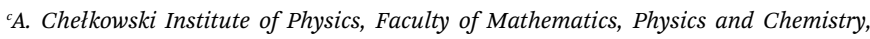
Silesian Center for Education and Interdisciplinary Research, University of Silesia, 75 Pulku Piechoty 1A, 41-500 Chorzów, Poland

$\dagger$ Electronic supplementary information (ESI) available. See DOI: $10.1039 / \mathrm{c} 9 \mathrm{ra} 02655 \mathrm{j}$

cycloaddition of azides and terminal alkynes what has further triggered the possibility of comprehensive research on both the structure and synthesis of that heterocycles. ${ }^{18}$ The widely used $\mathrm{Cu}(\mathrm{I})$-catalyzed method offers many advantages such as exclusive regioselectivity, a wide substrate scope, and mild reaction. ${ }^{19,20}$

As abovementioned, we have already presented the preparation of a series of $4^{\prime}$-(1-substituted-2,3-triazol-4-yl)phenyl$2,2^{\prime}: 6^{\prime}, 2^{\prime \prime}$-terpyridine derivatives and investigation of their photophysical and thermal properties and antiproliferative activity. ${ }^{21}$ We have found that in the case of the (1-substituted)2,3-triazol-4-yl ring, the change in the substituents has an insignificant effect on its photophysical properties, and identical maxima of absorption and emission and values of lifetime have been observed; however, the quantum yields are different. Moreover, biological studies conducted on a panel of cancer cells showed that the studied compounds exhibited good anticancer activity at the nanomolar level with a good selectivity index, and the mechanism of action could be described as the interaction of these compounds with the DNA of cells.

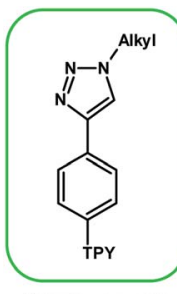

Previous work

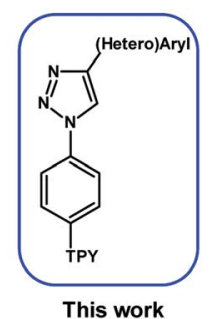

Fig. $14^{\prime}$-Phenyl-2,2':6', $2^{\prime \prime}$-terpyridine derivatives containing a 1,2,3triazole motif. 
In this study, we present the synthesis routes of $4^{\prime}-(1-$ substituted-2,3-triazol-4-yl)phenyl-2,2' $: 6^{\prime}, 2^{\prime \prime}$-terpyridines along with the studies of their optical, thermal, electrochemical, and biological activity, and particular emphasis was placed on the influence of the nature of substituents at the 1,2,3-triazol ring on the properties of these compounds; this allowed us to find the most promising materials. The proper understating of a part of the experimental results was supported by theoretical calculations (DFT and TD-DFT).

\section{Results and discussion}

\subsection{Synthesis and structural characterization}

The structures of the designed $4^{\prime}$-phenyl-2,2' $: 6^{\prime}, 2^{\prime \prime}$-terpyridine derivatives with the substituents A1-A7 are presented in Fig. 2.

The first approach to the synthesis of target $4^{\prime}$-phenyl$2,2^{\prime}: 6^{\prime}, 2^{\prime \prime}$-terpyridine derivatives with the 1,2,3-triazolyl ring substituted by the various aryl and heteroaryl groups A1-A7, as presented in Scheme 1, started with the substitution of the nitro group in 4-nitrobenzaldehyde by the azide anion; this resulted in the production of 1 with a $78 \%$ yield $;^{22}$ in the next step, 1 was subjected to a 1,3-dipolar cycloaddition reaction that provided the 1,2,3-triazole ring 2 substituted at the position 1 by a 4 formylphenyl group and at the position 4 by an aryl or heteroaryl group. Subsequently, the obtained product was used as a substrate in the next stage of synthesis, i.e. the aldol condensation reaction, resulting in the formation of the target compounds 3A1-3A7.

However, due to the low yields of individual steps, related ethynylaryl and heteroaryl losses, problems with the purification of intermediates, multiple column chromatography procedures, polarity of products and affinity towards the stationary phase, it was decided to develop a new synthetic route for target compounds.

Another synthetic strategy was to minimize substrate losses by introducing aryl and heteroaryl groups into the structure only at the last stage of the synthesis. Therefore, attempts have been made to synthesize $4^{\prime}$-(4-azidophenyl)-2,2 $2^{\prime}: 6^{\prime}, 2^{\prime \prime}$-terpyridine 4 by substituting a bromine atom or a nitro group by the azide substituent, similar to the reactions well known in the literature; ${ }^{23,24}$ however, the expected product is not obtained;

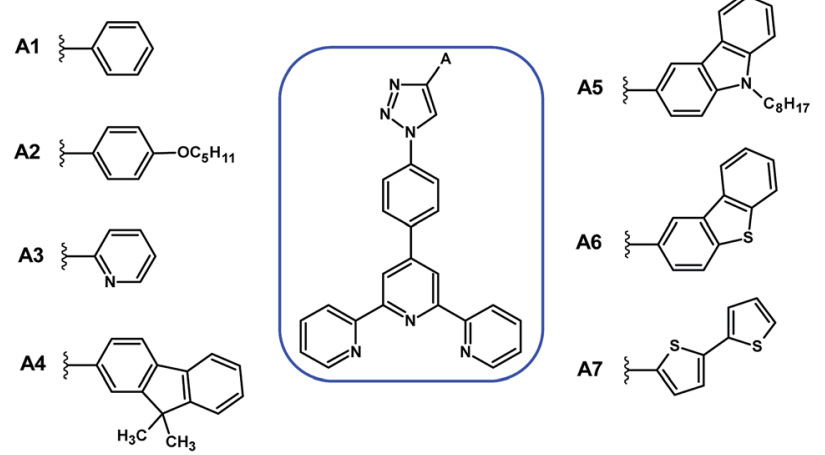

Fig. 2 Structures of the designed $4^{\prime}$-phenyl-2,2': $6^{\prime}, 2^{\prime \prime}$-terpyridine derivatives with the substituents A1-A7.

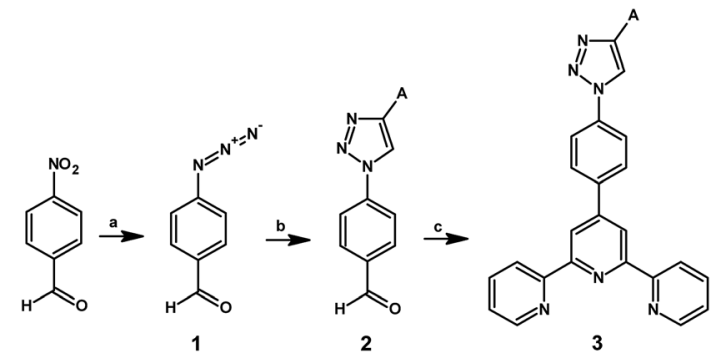

Scheme 1 Synthesis of the compounds 1-3. Reagents and conditions: (a) $\mathrm{NaN}_{3}, \mathrm{HMPA}$, room temp., and $72 \mathrm{~h}$; (b) ethynyl-derivative of $\mathrm{A}$, $\mathrm{CuSO}_{4} \cdot 5 \mathrm{H}_{2} \mathrm{O}$, sodium ascorbate, pyridine, $\mathrm{EtOH}, \mathrm{H}_{2} \mathrm{O}$, room temp., and $24 \mathrm{~h}$; and (c) 2-acetylpyridine, $\mathrm{KOH}, \mathrm{NH}_{3 a q}, \mathrm{EtOH}$, room temp., and $24 \mathrm{~h}$.

this can be probably caused by the absence of an electronwithdrawing group, such as an aldehyde group, in the structure.

Based on the presented results, a new synthetic route was developed (Scheme 2), in which 4-azidobenzaldehyde 1, previously obtained as a result of nucleophilic substitution, was used as the starting substrate, and in the next stage, it was used in the Kröhnke reaction to obtain $4^{\prime}$-(4-azidophenyl)-2, $2^{\prime}: 6^{\prime}, 2^{\prime \prime}$-terpyridine. Then, the obtained intermediate was subjected to a 1,3dipolar cycloaddition reaction with the corresponding ethynyl derivatives of the aryls and heteroaryls A1-A7. As a result, the products 3A1-3A7 with satisfactory yields, i.e. $21-42 \%$, were obtained, and purification processes, such as column chromatography, were not required. The crude product was purified by dissolving it in a small amount of $\mathrm{CHCl}_{3}$ and adding excess of hexane; it was then taken in a centrifuge tube that was then placed in an ultrasonic bath for $5 \mathrm{~min}$. The obtained precipitate was filtered through the fritted funnel G3 and washed with water and diethyl ether. The novel compounds 3A1-3A7 were fully characterized by the spectroscopic methods ${ }^{1} \mathrm{H}$ and ${ }^{13} \mathrm{C}$ NMR and mass spectrometry (ESI Fig. S6-S29†).

\subsection{Thermal studies}

Thermal properties of the presented compounds 3A1-3A7 and 4 were examined by thermogravimetric analysis (TGA) (under a nitrogen atmosphere at the heating rate of $15{ }^{\circ} \mathrm{C} \mathrm{min}^{-1}$ ). Before the measurement, the samples were dried under vacuum

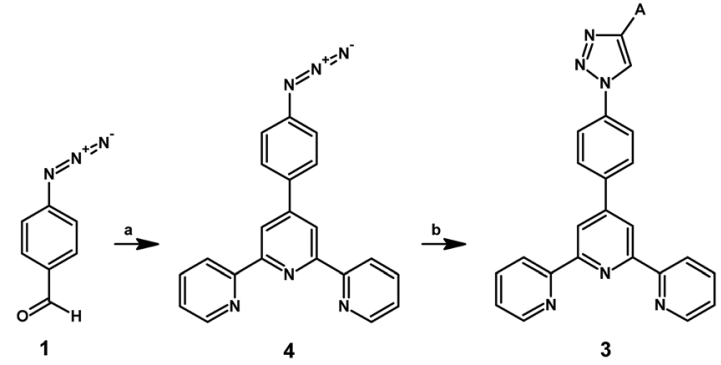

Scheme 2 Synthesis of the compounds 4 and 3. Reagents and conditions: (a) 2-acetylpyridine, $\mathrm{KOH}, \mathrm{NH}_{3 a q}, \mathrm{EtOH}$, room temp., and $24 \mathrm{~h}$ and (b) ethynyl derivative of $\mathrm{A}, \mathrm{CuSO}_{4} \cdot 5 \mathrm{H}_{2} \mathrm{O}$, sodium ascorbate, pyridine, $\mathrm{EtOH}, \mathrm{H}_{2} \mathrm{O}$, room temp., and $24 \mathrm{~h}$. 
$\left(0.2 \mathrm{mbar}\right.$ and $\left.80^{\circ} \mathrm{C}\right)$ for $6 \mathrm{~h}$. The results are shown in Table 1 , and Fig. 3 presents the TGA curves for all compounds. The DTG and TGA curves for each compound 3A1-3A7 and 4 are separately presented in the ESI Fig. $\mathrm{S} 1 . \dagger$

The target compounds 3A1-3A7 have high thermal stability. The temperature of decomposition, which corresponds to a $5 \%$ sample weight loss for the presented $2,2^{\prime}: 6^{\prime}, 2^{\prime \prime}$-terpyridine derivatives, is higher than $315{ }^{\circ} \mathrm{C}$ and highest for 3A6, which contains the dibenzothiophenyl substituent; on the other hand, the substrate, assigned as 4, used for the synthesis of compounds 3A1-3A7, shows significantly lower thermal stability up to $227^{\circ} \mathrm{C}$. Moreover, the char residue at $900{ }^{\circ} \mathrm{C}$ for all the examined compounds is higher than $25 \%$, characteristic for molecules containing aromatic rings, which have the tendency to yield some char residues that are stable under a nitrogen atmosphere even at very high temperatures. Moreover, the DTG curves (presented in the ESI $\dagger$ ) revealed that the compounds exhibited weight-loss peaks ranging from one to three.

\subsection{Theoretical studies}

Quantum mechanical calculations based on density functional theory and time-dependent density functional theory were performed to obtain information about the geometry and the optical properties of the novel terpyridine derivatives 3A1-3A7. The B3LYP exchange-correlation functional with the $6-31 \mathrm{G}^{* *}$ basis set implemented in the Gaussian 09 program was used. ${ }^{25}$ The B3LYP/6-31G** geometries were optimized in a chloroform solution in the polarisable continuous model. ${ }^{26}$ The obtained results of optimized geometries (stationary state as an energy minimum was confirmed by the frequency calculations) with contours of frontier orbitals, contribution of substituents to the creation of HOMOs and LUMOs, and the values of the energy gap $(\Delta E)$ are presented in Table 2 .

The optimized geometries of 3A1-3A7 show that the 1,2,3triazole ring and the substituents A1-A7 are coplanar, whereas the phenyl ring and $2,2^{\prime}: 6^{\prime}, 2^{\prime \prime}$-terpyridine are twisted. The values of the energy gaps are in the range of 3.58-4.54 eV, and highest values are obtained for $\mathbf{3 A 3}(4.54 \mathrm{eV})$ and $\mathbf{3 A 3}(4.35 \mathrm{eV})$. The HOMOs are mainly localized on 4-substituted-1,2,3-triazol-4-yl groups, and the contribution of a substituent is highest for

Table 1 Thermal properties of the synthesized derivatives 3A1-3A7 and $4^{a}$

\begin{tabular}{lllll}
\hline \multicolumn{3}{c}{ TGA } \\
\cline { 2 - 4 } & $T_{5 \%}\left[{ }^{\circ} \mathrm{C}\right]$ & $T_{10 \%}\left[{ }^{\circ} \mathrm{C}\right]$ & $T_{\max }\left[{ }^{\circ} \mathrm{C}\right]$ & Char residue at $900{ }^{\circ} \mathrm{C}[\%]$ \\
\hline 3A1 & 325 & 358 & 416 & 25 \\
3A2 & 348 & 388 & 471 & 33 \\
3A3 & 318 & 343 & 373 & 36 \\
3A4 & 327 & 353 & 498 & 29 \\
3A5 & 333 & 372 & 496 & 29 \\
3A6 & 389 & 421 & 519 & 42 \\
3A7 & 317 & 346 & 376,471 & 39 \\
4 & 227 & 318 & $216,372,527$ & 25 \\
${ }^{a} T_{5 \%}, T_{10 \%}-$ the temperature of $5 \%$ and $10 \%$ weight loss, $T_{\max }-$ the \\
maximum decomposition rate obtained from the DTG thermograms.
\end{tabular}

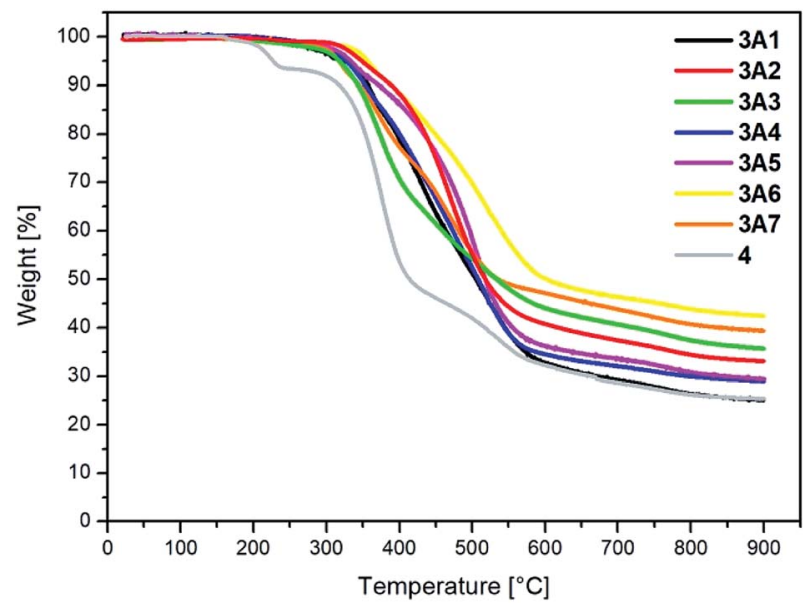

Fig. 3 TGA curves of $3 A 1-3 A 7$ and 4 .

3A5, which contains a carbazolyl group (84\%), and lowest for 3A3 with a pyridyl group (31\%). In the case of $\mathbf{3 A 1}$ and $\mathbf{3 A 3}$, the highest occupied molecular orbital is also located on the phenyl ring, which is directly connected to the central pyridine ring of terpyridine (contribution of the phenyl ring for $\mathbf{3 A 1}$ is $12 \%$, and that for $\mathbf{3 A 3}$ is $21 \%$ ). The distribution of LUMOs is similar in the case of the compounds 3A1-3A6, where the mentioned frontier orbitals are localized on the phenyl, 1,2,3-triazol, and central pyridine ring of terpyridine, and the participation of the side pyridine rings of terpyridine is slight. The compound 3A7, which contains electron-donating substituents at the 1,2,3-triazole ring also has the lowest unoccupied molecular orbital localized on the substituent 2,2'-bithiophene (19\%), whereas the participation of the substituents for 3A1-3A6 is slight (1$3 \%)$.

\subsection{UV-Vis absorption, photoluminescence, and TD-DFT study}

A number of systematic studies have been reported on the photophysical properties of $2,2^{\prime}: 6^{\prime}, 2^{\prime \prime}$-terpyridine derivatives with different aromatic peripheral substituents. Although the presence of a 1,2,3-triazole group in the terpyridine skeleton has been rarely introduced, ${ }^{21}$ it can infer an important effect on the optical properties of the terpyridine derivatives and thus their application in optoelectronics and medicine. The photophysical and electronic properties of 3A1-3A7 in a chloroform solution were studied by UV-Vis and fluorescence (PL) spectroscopy to investigate the relation between the character of the substituted triazole unit in 3A1-3A7 and the photophysical behaviour of these compounds. The photoluminescence data, lifetime and quantum yields are listed in Table 3 .

The compounds 3A1-3A7 have displayed almost identical absorption maxima centered around $275 \mathrm{~nm}$, which can be assigned to the $\pi \rightarrow \pi^{*}$ transitions of the conjugated system (Fig. 4a). In the case of compound 3A7, an additional band appears at $330 \mathrm{~nm}$, which can be clarified by the distribution of the electron density of LUMO on the 2,2'-bithiophene as well as terpyridine units as compared to the case of other compounds, where LUMO is mostly centered on the 
Table 2 Contours, energies, and contribution to the creation of HOMOs and LUMOs of 3A1-3A7

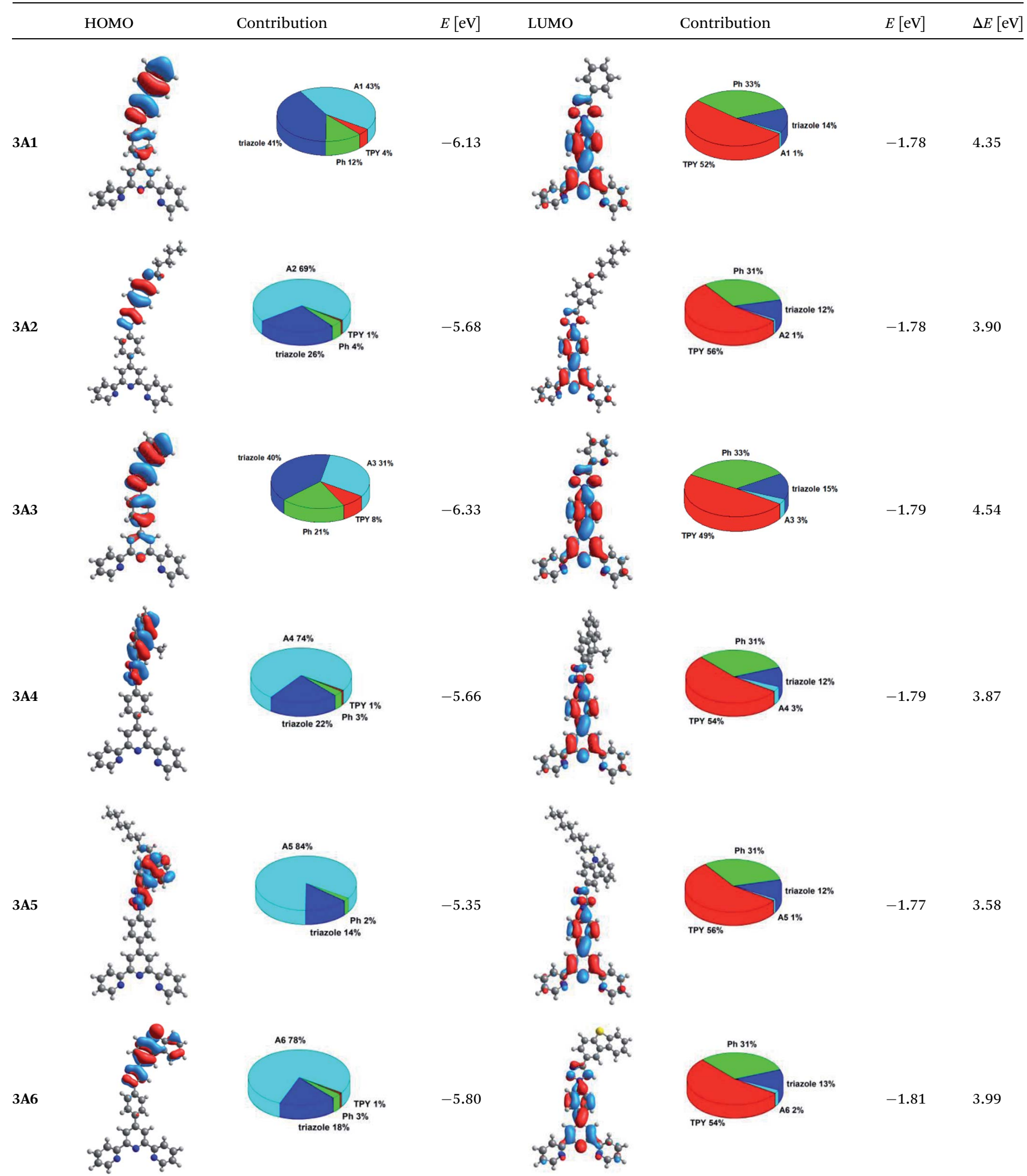


Table 2 (Contd.)

\begin{tabular}{|c|c|c|c|c|c|c|c|}
\hline & HOMO & Contribution & $E[\mathrm{eV}]$ & LUMO & Contribution & $E[\mathrm{eV}]$ & $\Delta E[\mathrm{eV}]$ \\
\hline & & A7 $79 \%$ & & & $\mathrm{Ph} 27 \%$ & & \\
\hline 3A7 & & & -5.45 & & & -1.86 & 3.59 \\
\hline
\end{tabular}

terpyridine part; this low energy absorption band can be ascribed to an intramolecular charge transfer (ICT) transition originating partly from a strong donor $\left(2,2^{\prime}\right.$-bithiophene) to an acceptor (terpyridine) moiety.

The results of the TD-DFT calculations that have also been carried out at the B3LYP level of theory with the $6-31 \mathrm{G}^{* *}$ basis set are listed for $\mathbf{3 A 1}$ and $\mathbf{3 A} \mathbf{7}$ in Table 4 (presenting the calculated wavelengths of the absorption bands, oscillator strengths, and transitions); moreover, data for 3A2-3A6 are presented in the ESI Table S1. $\dagger$ Note that an additional absorption band for 3A7 $(330 \mathrm{~nm})$ also appeared, as observed via theoretical calculations, which had the same character as the lowest energy bands for the compounds 3A1-3A6; however, it was shifted to longer wavelength.

The photoluminescence spectra of $\mathbf{3 A 1}-\mathbf{3 A} \mathbf{7}$ presented in Fig. $4 \mathrm{~b}$ indicate the influence of the substituent at the position 4 of the triazole unit, and the excitation spectra are presented in the ESI Fig. S2. $\dagger$ The electronic ability of the substituents in 3A1-3A7 robustly changes their emission spectra. The compound $\mathbf{3 A 1}$ with a weak electron-donating phenyl substituent possesses a similar emission maximum as the compound $\mathbf{3} \mathbf{A} \mathbf{3}$ with the electronwithdrawing pyridine unit. Moreover, electron-donating substituents in $\mathbf{3 A 2}$ and $\mathbf{3 A 4}-\mathbf{3 A 7}$ cause a pronounced bathochromic shift of the emission maximum. The range of this shift is dependent on the electron-donating character and geometry of the substituents. Introduction of $p$-pentoxyphenyl, fluorene, and dibenzothiophene units into the triazole ring in $\mathbf{3 A 2}, \mathbf{3 A 4}$ and $\mathbf{3 A 6}$, respectively, results in a red shift of the emission maximum from $3 \mathbf{A 6}(378 \mathrm{~nm})$ through 3A4 $(392 \mathrm{~nm})$ to $\mathbf{3 A 2}(396 \mathrm{~nm})$ due to the stronger donor ability of these groups. Among the reported compounds, 3A5 possesses the longest emission at $442 \mathrm{~nm}$ probably owing to the strong influence of its substituent on the electron density of conjugated bonds. In addition, for the compounds $\mathbf{3 A 2}$ and 3A43A7, HOMOs are mostly situated on the A groups with contribution in the range of $69-84 \%$, whereas the LUMOs are mainly delocalized on the terpyridine, phenyl, and triazole parts, indicating highly separated and red-shifted transition bands in the emission spectrum.

Based on the theoretical calculations, it can also be proved that the emission of the compounds $\mathbf{3 A 1}-\mathbf{3 A 7}$ strongly depends on the substituents due to the character of transitions that can be assigned as transfer of electrons from HOMO to LUMO. Only in the case of 3A3, double emission was observed with a mixed character of transitions, as also observed via the experimental data (Table 5).

The quantum yields of fluorescence for 3A1-3A7 are in the range of $7-41 \%$ and differ depending on the type of substituents. The compounds $\mathbf{3 A 5}$ and $\mathbf{3 A 7}$ with pronounced red-shifted emission bands display highest quantum yields $\left(\Phi_{\mathrm{F}}=30-41 \%\right)$. The measured effective lifetime values are from 0.41 to $4.21 \mathrm{~ns}$. The monoexponential fit was evaluated in the case of the compound $\mathbf{3 A 2}$ and $\mathbf{3 A 4}$; however, for other compounds, the biexponential fit was attained (Fig. S3 in the ESI†).

\subsection{Electrochemical study}

Electrochemical properties of the target compounds 3A1-3A7 were investigated in a $0.1 \mathrm{M} \mathrm{Bu}_{4} \mathrm{NPF}_{6}$ solution in chloroform by cyclic voltammetry (CV) and differential pulse voltammetry (DPV), and the concentration of the solution was $1.0 \mathrm{mM} \mathrm{L}^{-1}$. The obtained

Table 3 Photophysical data for 3A1-3A7 obtained in the chloroform solution

\begin{tabular}{|c|c|c|c|c|c|c|c|}
\hline & $\lambda_{\max }[\mathrm{nm}]$ & $\lambda_{\mathrm{ex}}[\mathrm{nm}]$ & $\mathrm{PL} \lambda_{\mathrm{em}}[\mathrm{nm}]$ & $\Phi[\%]$ & $\tau_{\text {eff }}[\mathrm{ns}]($ weight $\%)$ & $\chi^{2}$ & $E_{\mathrm{g} \text { opt }}[\mathrm{eV}]$ \\
\hline 3A1 & 278 & 280 & 360 & 7 & $0.60[0.24(74.09), 1.64(25.91)]$ & 0.906 & 3.45 \\
\hline $3 \mathbf{A} 2$ & 274 & 318 & 396 & 20 & 0.73 & 0.972 & 3.13 \\
\hline 3A4 & 275 & 326 & 392 & 26 & 0.63 & 1.159 & 3.17 \\
\hline 3A5 & 276 & 324 & 442 & 41 & $4.21[0.11(5.92), 4.47(94.08)]$ & 0.998 & 2.81 \\
\hline 3A6 & 274 & 316 & 378 & 13 & $0.41[0.28(72.69), 0.76(27.31)]$ & 0.991 & 3.28 \\
\hline
\end{tabular}


(a)

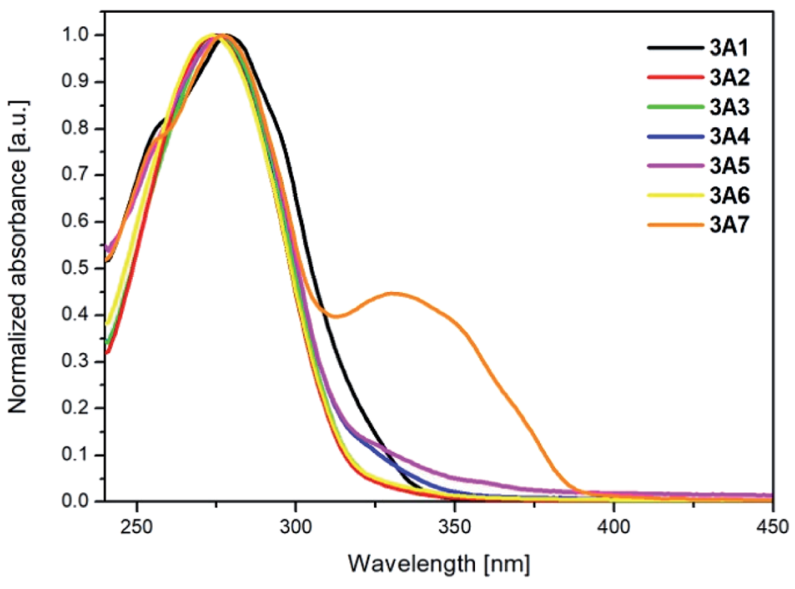

(b)

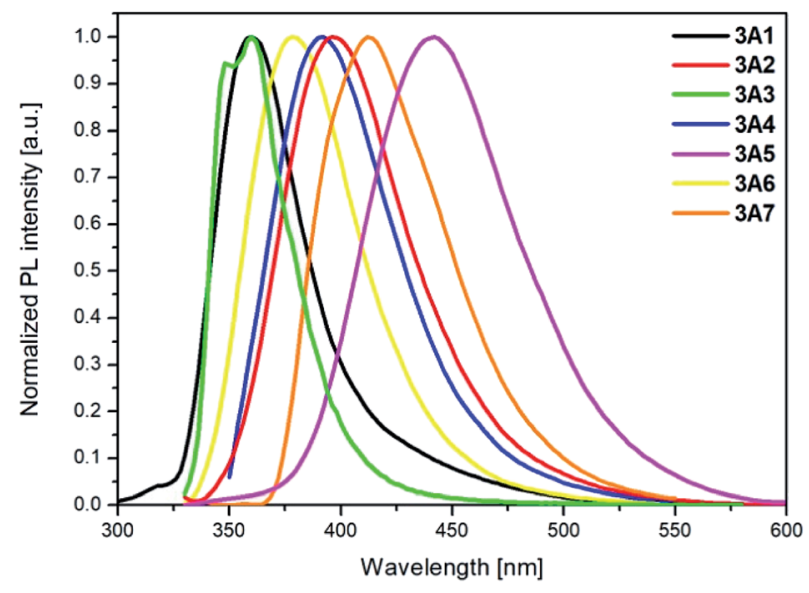

Fig. 4 (a) Absorption and (b) emission spectra obtained in $\mathrm{CHCl}_{3}$ ( $c=$ $10^{-5} \mathrm{~mol} \mathrm{~L}^{-1}$ ) for 3A1-3A7.

CV voltammograms for all compounds are presented in Fig. 5 . The DPV and CV voltammograms presented separately for every compound are shown in the ESI Fig. S4 and S5.†
The global structure of the investigated samples is same with various side substituents, leading to changes in electron density and hence ionization capability of the molecules. The lowest oxidation potential (and further ionization potential) was found for 3A6, which contained the electron-rich dibenzothiophene moiety. Similarly, the presence of an easily oxidizable $2,2^{\prime}$ bithiophene unit leads to low oxidation potential of $3 \mathbf{A} 7$. Substitution of a nitrogen atom into carbon in the fluorene moiety leads to an increase in the oxidation potential of $\mathbf{3 A 4}$ with the value similar to that of the alkoxyl-substituted phenyl ring $\mathbf{3 A 2}$, and this value increases upon sulfur substitution such as in the case of 3A6. Derivatives with the phenyl or pyridine ring undergo oxidation at the highest potentials.

The electrochemical oxidation and reduction onset potentials shall be utilized to calculate the HOMO and LUMO energies (which correspond to ionization potentials and electron affinities) of the materials. The IP of the ferrocene couple was calculated to be equal to $-5.1 \mathrm{eV}$, as shown by Pron $e t$ al. ${ }^{27}$ The calculated values are presented in Tables 6 and 7. The oxidation potentials were used to calculate the HOMO energy level. However, for LUMO calculation, the optically derived $E_{\mathrm{g}}$ value was used as the potential of the obtained reduction peaks, which did not match the oxidation potentials typical for a pyridine system. ${ }^{28}$ Based on the literature data, it was confirmed that the reduction peak potential belonged to a side product formed during the study which appeared as visible green coloration. ${ }^{29}$ Using the calculated LUMO level, predictive reduction potentials of the samples were calculated, which confirmed their position below $-2.5 \mathrm{eV}$, which was below the applied measurement potential border and could not be determined.

\subsection{Biological study}

Anticancer activity of the described terpyridine derivatives 3A13A7 was determined on two cancer cell lines: breast (MCF-7) and pancreatic (PANC-1). In Table 8, we present the $\mathrm{IC}_{50}$ values, which express the inhibitory concentration of $50 \%$ of the

Table 4 Wavelength maxima [nm] of the absorption spectra together with oscillator strengths calculated for the 3A1 and 3A7 molecules by the TD-DFT method

Calculated wavelengths [nm] (oscillator strengths) Transitions (contribution)

3A1 $316.10(0.64)$

$299.24(0.12)$

$275.42(0.46)$

$272.52(0.54)$

$264.42(0.13)$

$254.36(0.13)$

$251.34(0.23)$

$247.60(0.16)$

3A7 $383.88(0.74)$

$351.08(0.53)$

$301.50(0.16)$

$286.32(0.52)$

$283.89(0.13)$

$272.12(0.13)$

$263.94(0.20)$

$261.72(0.14)$

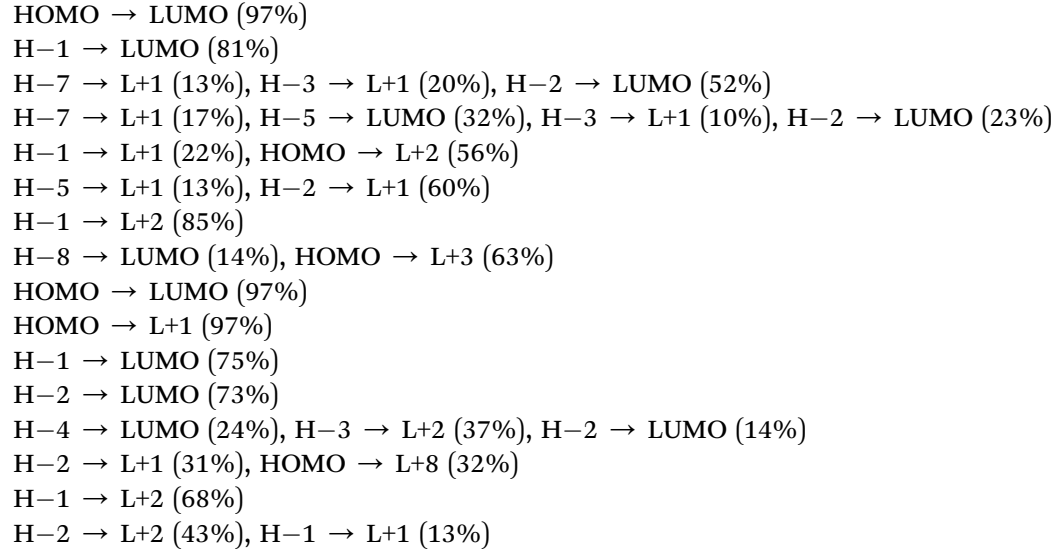


Table 5 Calculated TD-DFT wavelengths [nm] in the emission spectra and oscillator strengths for the 3A1-3A7 molecules

\begin{tabular}{lllll}
\hline & $\begin{array}{l}\text { Calculated wavelengths } \\
{[\mathrm{nm}] \text { (oscillator strengths) }}\end{array}$ & Experimental PL $\lambda_{\text {em }}[\mathrm{nm}]$ & $\begin{array}{l}\Delta \\
\text { (theoretical - experimental) }\end{array}$ & Transitions \\
\hline 3A1 & $384(1.09)$ & 360 & 24 & HOMO $\rightarrow$ LUMO (98\%) \\
3A2 & $432(0.43)$ & 396 & 36 & HOMO $\rightarrow$ LUMO $(99 \%)$ \\
3A3 & $331(0.10)$ & 348,360 & 17 & H-1 $\rightarrow$ LUMO $(86 \%)$ \\
& $374(1.51)$ & & 14 & HOMO $\rightarrow$ LUMO $(98 \%)$ \\
3A4 & $428(0.73)$ & 388 & 40 & HOMO $\rightarrow$ LUMO (98\%) \\
3A5 & $458(0.32)$ & 438 & 20 & HOMO $\rightarrow$ LUMO (99\%) \\
3A6 & $408(0.64)$ & 378 & 30 & HOMO $\rightarrow$ LUMO (98\%) \\
3A7 & $475(0.93)$ & 412 & 63 & HOMO $\rightarrow$ LUMO (99\%)
\end{tabular}

cell population. Moreover, we performed cytotoxicity assay for healthy cells (NHDF). The obtained $\mathrm{IC}_{50}$ values for MCF-7 and PANC-1 are comparable. However, we noticed that the MCF-7 line was slightly more resistant to the investigated terpyridines. The most active derivative proved to be $\mathbf{3 A 3}$ on the PANC1 cells $\left(\mathrm{IC}_{50}=0.114 \mu \mathrm{M}\right)$ with lowest lipophilicity. Moreover, TI was calculated as a ratio of the $\mathrm{IC}_{50}$ normal cells to the $\mathrm{IC}_{50}$ cancer cells. We could find a correlation between the anticancer activity and $\log P$. The less active compound 3A5 has highest $\log P$ value. Moreover, the $\mathbf{3 A 3}$ derivative exhibited best TI,

(a)

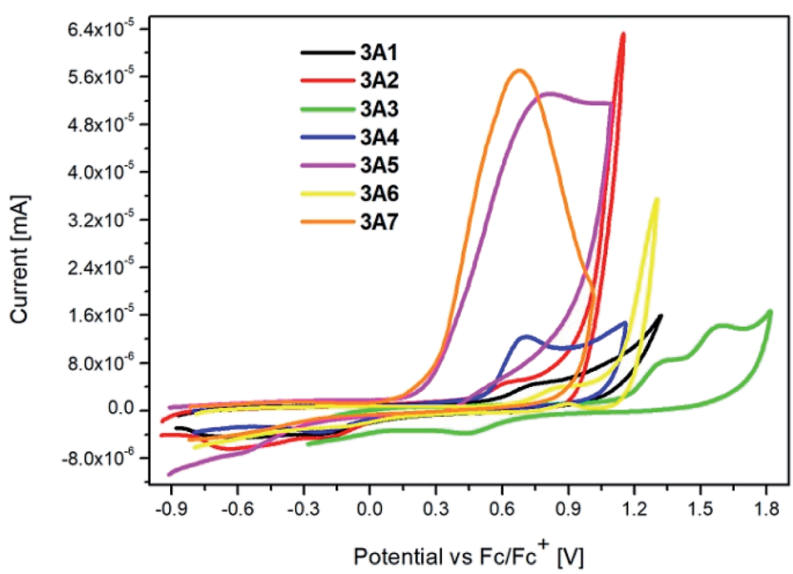

(b)

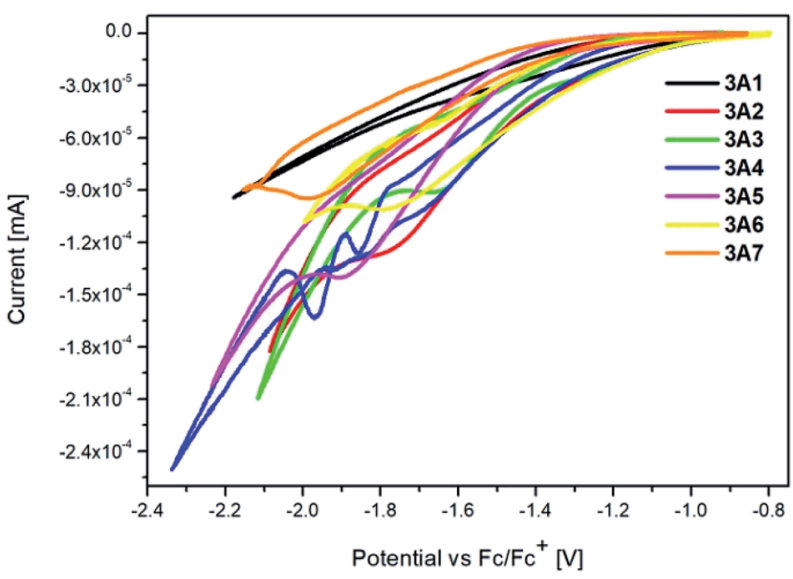

Fig. 5 Cyclic voltammetry (CV): (a) oxidation, (b) reduction of 3A13A7 (scan rate $0.100 \mathrm{~V} \mathrm{~s}^{-1}$, electrolyte $0.1 \mathrm{M} \mathrm{Bu}_{4} \mathrm{NPF}_{6}$ in the $\mathrm{CHCl}_{3}$ solution). which was equal to 219.3. Overall, three (3A1, 3A2, 3A3) of the tested compounds possess $\mathrm{IC}_{50}$ values below $1 \mu \mathrm{M}$, with high TI, which makes them an interesting target for further research.

\section{Experimental}

\subsection{Materials}

All chemicals were commercially available and used without purification. Solvents were distilled and purged with nitrogen before use. All reactions were carried out under an argon atmosphere.

\subsection{4-(4-Azidophenyl)-2, $2^{\prime}: 6^{\prime}, 2^{\prime \prime}$-terpyridine (4)}

4-Azidobenzaldehyde $(5.40 \mathrm{mmol}, 0.80 \mathrm{~g}), 2$-acetylpyridine $(10.80 \mathrm{mmol}, 1.22 \mathrm{~mL})$ and $50 \mathrm{~mL}$ ethanol were placed in a $150 \mathrm{~mL}$ conical flask and mixed for 5 minutes. Then, $\mathrm{KOH}$ (14.86 mmol, $0.84 \mathrm{~g}$ ) and $25 \mathrm{~mL}$ concentrated solution of ammonia were added. The resulting solution was stirred at room temperature for 24 hours. The obtained precipitate was filtered through the fritted funnel G3 and washed with water, ethanol and diethyl ether; this resulted in the formation of the product as a yellowish crystalline solid $(0.99 \mathrm{~g}, 52 \%)$.

${ }^{1} \mathrm{H}$ NMR $\left(400 \mathrm{MHz}, \mathrm{CDCl}_{3}\right) \delta 8.73-8.70(\mathrm{~m}, 2 \mathrm{H}), 8.68(\mathrm{~d}, J=$ $4.5 \mathrm{~Hz}, 2 \mathrm{H}), 8.67-8.63(\mathrm{~m}, 2 \mathrm{H}), 7.91-7.82(\mathrm{~m}, 3 \mathrm{H}), 7.78-7.74(\mathrm{~m}$, $1 \mathrm{H}), 7.33$ (tdd, $J=7.8,4.8,1.1 \mathrm{~Hz}, 2 \mathrm{H}), 7.16-7.11(\mathrm{~m}, 1 \mathrm{H}), 6.80-$ $6.75(\mathrm{~m}, 1 \mathrm{H})$.

${ }^{13} \mathrm{C}$ NMR $\left(101 \mathrm{MHz}, \mathrm{CDCl}_{3}\right) \delta 156.66,156.26,156.13,155.84$, 150.08, 149.24, 149.17, 147.70, 141.02, 137.00, 136.90, 135.23, $128.85,128.48,124.00,123.76,121.49,119.64,118.54,117.88$, 115.33 .

HRMS (ESI): $m / z$ calcd for $\mathrm{C}_{21} \mathrm{H}_{15} \mathrm{~N}_{6}: 351.1358\left[\mathrm{MH}^{+}\right]$; found 351.1352 .

\subsection{1,3-Dipolar cycloaddition for the synthesis of 3A1-3A7}

General procedure. In a $50 \mathrm{~mL}$ round-bottomed flask, $4^{\prime}$-(4azidophenyl)-2, $2^{\prime}: 6^{\prime}, 2^{\prime \prime}$-terpyridine ( $\left.0.063 \mathrm{~g}, 0.18 \mathrm{mmol}\right)$, ethanol $(7 \mathrm{~mL})$ and water $(3 \mathrm{~mL})$ were placed. The mixture was saturated with argon for 15 minutes and then appropriate amount of ethynyl aryl $(0.22 \mathrm{mmol})$ (in the case of ethynyl derivatives protected by trimethylsilyl, the silyl group was removed in situ using KF (0.048 g, $0.22 \mathrm{mmol})$ ), sodium ascorbate ( $0.044 \mathrm{~g}, 0.22$ $\mathrm{mmol}), \mathrm{CuSO}_{4} \cdot 5 \mathrm{H}_{2} \mathrm{O}(0.055 \mathrm{~g}, 0.22 \mathrm{mmol})$, and pyridine $(0.15$ $\mathrm{mL})$ were added. The mixture was stirred at room temperature for $48 \mathrm{~h}$. Then, chloroform $(20 \mathrm{~mL})$ and a $5 \%$ solution of 
Table 6 Electrochemical data of cyclic voltammetry (CV) for 3A1-3A7 obtained in the $\mathrm{CHCl}_{3}$ solution ${ }^{a}$

\begin{tabular}{|c|c|c|c|c|c|c|c|}
\hline & $E_{(\mathrm{CV})}^{\mathrm{ox}}$ & $E_{\text {onset(CV) }}^{\text {ox }}$ & HOMO [eV] & $E_{\mathrm{red}(\mathrm{CV})}^{*}$ & $E_{\text {onset(CV) }}^{\text {red }}$ & LUMO $[\mathrm{eV}]$ & $\begin{array}{l}E_{\mathrm{g}} \\
\text { opt }[\mathrm{eV}]\end{array}$ \\
\hline 3A1 & 1.02 & 0.93 & -6.03 & -1.81 & -2.72 & -2.38 & 3.65 \\
\hline $3 \mathbf{A} 2$ & 0.63 & 0.51 & -5.61 & -1.76 & -3.31 & -1.79 & 3.82 \\
\hline 3A3 & 1.32 & 1.14 & -6.24 & -1.65 & -2.68 & -2.42 & 3.82 \\
\hline 3A4 & 0.70 & 0.50 & -5.60 & -1.69 & -3.04 & -2.06 & 3.54 \\
\hline 3A5 & 0.85 & 0.69 & -5.79 & -1.80 & -3.13 & -1.97 & 3.82 \\
\hline 3A6 & 0.77 & 0.21 & -5.31 & -1.88 & -3.23 & -1.87 & 3.44 \\
\hline 3A7 & 0.83 & 0.30 & -5.40 & -1.98 & -2.96 & -2.14 & 3.26 \\
\hline
\end{tabular}

ammonia (15 mL) were added, and the mixture was stirred for additional time. The mixture was extracted with water $(50 \mathrm{~mL})$ and $\mathrm{CHCl}_{3}(2 \times 50 \mathrm{~mL})$. The combined organic layers were evaporated, and the crude product was dissolved in a small amount of $\mathrm{CHCl}_{3}$; then, excess of hexane was added, and the mixture was placed in a centrifuge tube that was then placed in an ultrasonic bath for $5 \mathrm{~min}$. The obtained precipitate was filtered through the fritted funnel G3 and washed with water and diethyl ether.

$3 \mathrm{A1}$ (34 mg, 42\%) as a brown solid. ${ }^{1} \mathrm{H}$ NMR $(400 \mathrm{MHz}$, $\left.\mathrm{CDCl}_{3}\right) \delta 8.79(\mathrm{~s}, 2 \mathrm{H}), 8.77-8.73(\mathrm{~m}, 2 \mathrm{H}), 8.70(\mathrm{~d}, J=8.0 \mathrm{~Hz}, 2 \mathrm{H})$, 8.29 (s, 1H), 8.12-8.07 (m, 2H), 7.97 (dd, $J=11.7,4.8 \mathrm{~Hz}, 4 \mathrm{H}$ ), $7.91(\mathrm{td}, J=7.7,1.8 \mathrm{~Hz}, 2 \mathrm{H}), 7.49(\mathrm{dd}, J=10.3,4.7 \mathrm{~Hz}, 2 \mathrm{H}), 7.42-$ $7.35(\mathrm{~m}, 3 \mathrm{H})$.

${ }^{13} \mathrm{C}$ NMR $\left(101 \mathrm{MHz}, \mathrm{CDCl}_{3}\right) \delta 156.38,156.17,149.35,148.86$, 148.78, 139.16, 137.59, 137.12, 130.33, 129.11, 128.93, 128.68, 126.10, 124.18, 121.58, 120.89, 118.86, 117.57 .

HRMS (ESI): $m / z$ calcd for $\mathrm{C}_{29} \mathrm{H}_{21} \mathrm{~N}_{6}$ : $453.1828\left[\mathrm{MH}^{+}\right]$; found 453.1814 .

$3 \mathrm{~A} 2(39 \mathrm{mg}, 40 \%)$ as a beige solid. ${ }^{1} \mathrm{H} \mathrm{NMR}\left(400 \mathrm{MHz}, \mathrm{CDCl}_{3}\right)$ $\delta 8.79(\mathrm{~s}, J=2.1 \mathrm{~Hz}, 2 \mathrm{H}), 8.75$ (ddd, $J=4.8,1.8,0.8 \mathrm{~Hz}, 2 \mathrm{H}$ ), 8.72-8.70 (m, 1H), 8.70-8.68 (m, 1H), $8.19(\mathrm{~s}, 1 \mathrm{H}), 8.10(\mathrm{t}, J=$ $2.2 \mathrm{~Hz}, 1 \mathrm{H}), 8.09-8.07(\mathrm{~m}, 1 \mathrm{H}), 7.99-7.94(\mathrm{~m}, 2 \mathrm{H}), 7.91(\mathrm{td}, J=$ 7.7, $1.8 \mathrm{~Hz}, 2 \mathrm{H}), 7.88-7.84(\mathrm{~m}, 2 \mathrm{H}), 7.38$ (ddd, $J=7.6,4.7$, $1.2 \mathrm{~Hz}, 2 \mathrm{H}), 7.03-6.98(\mathrm{~m}, 2 \mathrm{H}), 4.02(\mathrm{t}, J=6.6 \mathrm{~Hz}, 2 \mathrm{H}), 1.87-1.77$ $(\mathrm{m}, 2 \mathrm{H}), 1.52-1.36(\mathrm{~m}, 4 \mathrm{H}), 0.95(\mathrm{t}, J=7.2 \mathrm{~Hz}, 3 \mathrm{H})$.

${ }^{13} \mathrm{C}$ NMR $\left(101 \mathrm{MHz}, \mathrm{CDCl}_{3}\right) \delta 159.67,156.38,156.19,149.35$, 148.91, 148.74, 139.03, 137.68, 137.13, 128.91, 127.38, 124.17, $122.78,121.59$, 120.83, 118.87, 116.68, 115.10, 68.29, 29.13, $28.37,22.63,14.18$.
HRMS (ESI): $m / z$ calcd for $\mathrm{C}_{34} \mathrm{H}_{31} \mathrm{~N}_{6} \mathrm{O}: 539.2559\left[\mathrm{MH}^{+}\right]$; found 539.2558 .

3A3 (28 mg, 34\%) as a brown solid. ${ }^{1} \mathrm{H}$ NMR $(400 \mathrm{MHz}$, $\left.\mathrm{CDCl}_{3}\right) \delta 8.79(\mathrm{~s}, 2 \mathrm{H}), 8.75(\mathrm{dd}, J=5.0,2.0 \mathrm{~Hz}, 2 \mathrm{H}), 8.71-8.68(\mathrm{~m}$, $3 \mathrm{H}), 8.66-8.63(\mathrm{~m}, 1 \mathrm{H}), 8.29$ (d, $J=7.9 \mathrm{~Hz}, 1 \mathrm{H}), 8.12(\mathrm{~d}, J=$ $2.1 \mathrm{~Hz}, 1 \mathrm{H}), 8.10(\mathrm{t}, J=2.4 \mathrm{~Hz}, 1 \mathrm{H}), 8.01(\mathrm{q}, J=2.6 \mathrm{~Hz}, 1 \mathrm{H}), 7.98$ $(\mathrm{dd}, J=5.2,2.5 \mathrm{~Hz}, 1 \mathrm{H}), 7.90(\mathrm{td}, J=7.7,1.9 \mathrm{~Hz}, 2 \mathrm{H}), 7.84(\mathrm{td}, J$ $=7.8,1.9 \mathrm{~Hz}, 1 \mathrm{H}), 7.38$ (ddd, $J=7.7,4.7,1.1 \mathrm{~Hz}, 2 \mathrm{H}), 7.29$ (ddd, $J=7.7,5.0,1.2 \mathrm{~Hz}, 1 \mathrm{H})$.

${ }^{13} \mathrm{C}$ NMR $\left(101 \mathrm{MHz}, \mathrm{CDCl}_{3}\right) \delta 156.39,156.17,150.07,149.71$, $149.35,148.81,139.28,137.52$, 137.20, 137.11, 128.98, 124.16, 123.33, 121.56, 120.84, 120.69, 120.01, 118.87 .

HRMS (ESI): $m / z$ calcd for $\mathrm{C}_{28} \mathrm{H}_{20} \mathrm{~N}_{7}: 454.1780\left[\mathrm{MH}^{+}\right]$; found 454.1769 .

$3 \mathrm{A4}$ (21 $\mathrm{mg}, 21 \%)$ as a brown solid. ${ }^{1} \mathrm{H}$ NMR $(400 \mathrm{MHz}$, $\left.\mathrm{CDCl}_{3}\right) \delta 8.78(\mathrm{~s}, 2 \mathrm{H}), 8.75(\mathrm{~d}, J=4.0 \mathrm{~Hz}, 2 \mathrm{H}), 8.69(\mathrm{~d}, J=$ $7.9 \mathrm{~Hz}, 2 \mathrm{H}), 8.32(\mathrm{~s}, 1 \mathrm{H}), 8.11-8.05(\mathrm{~m}, 3 \mathrm{H}), 7.97(\mathrm{~d}, J=8.5 \mathrm{~Hz}$, $2 \mathrm{H}), 7.93-7.85(\mathrm{~m}, 3 \mathrm{H}), 7.80(\mathrm{~d}, J=7.8 \mathrm{~Hz}, 1 \mathrm{H}), 7.76(\mathrm{dd}, J=$ $5.8,2.4 \mathrm{~Hz}, 1 \mathrm{H}), 7.47$ (dd, $J=5.7,2.5 \mathrm{~Hz}, 1 \mathrm{H}), 7.40-7.32(\mathrm{~m}$, $4 \mathrm{H}), 1.57$ (s, 6H).

${ }^{13} \mathrm{C}$ NMR $\left(101 \mathrm{MHz}, \mathrm{CDCl}_{3}\right) \delta 156.34,156.14,154.57$, 154.09, 149.32, 149.17, 148.80, 139.80, 139.05, 138.85, 137.58, 137.10, 129.17, 128.88, 127.65, 127.21, 125.06, 124.16, 122.81, $121.56,120.83$, 120.59, 120.39, 120.28, 118.81, 117.44, 47.19, 27.30 .

HRMS (ESI): $m / z$ calcd for $\mathrm{C}_{38} \mathrm{H}_{29} \mathrm{~N}_{6}: 569.2454\left[\mathrm{MH}^{+}\right]$; found 569.2444 .

3A5 (27 mg, 23\%) as a brown solid. ${ }^{1} \mathrm{H}$ NMR $(400 \mathrm{MHz}$, $\left.\mathrm{CDCl}_{3}\right) \delta 8.79(\mathrm{~s}, 2 \mathrm{H}), 8.76(\mathrm{~d}, J=4.0 \mathrm{~Hz}, 2 \mathrm{H}), 8.70(\mathrm{~d}, J=$ $8.4 \mathrm{~Hz}, 3 \mathrm{H}), 8.32(\mathrm{~s}, 1 \mathrm{H}), 8.18(\mathrm{~d}, J=7.7 \mathrm{~Hz}, 1 \mathrm{H}), 8.09$ (d, $J=$

Table 7 Electrochemical data of differential pulse voltammetry (DPV) for 3A1-3A7 obtained in the $\mathrm{CHCl}_{3}$ solution $^{a}$

\begin{tabular}{|c|c|c|c|c|c|c|c|}
\hline & $E_{(\mathrm{DPV})}^{\mathrm{ox}}$ & $E_{\text {onset(DPV) }}^{\text {ox }}$ & HOMO $[\mathrm{eV}]$ & $E_{\mathrm{red}(\mathrm{DPV})}^{*}$ & $E_{\text {onset(DPV) }}^{\text {red }}$ & LUMO $[\mathrm{eV}]$ & $E_{\mathrm{g} \text { opt }}[\mathrm{eV}]$ \\
\hline 3A1 & 1.31 & 0.91 & -6.01 & - & -2.74 & -2.36 & 3.65 \\
\hline 3A2 & 0.52 & 0.49 & -5.59 & -1.52 & -3.33 & -1.77 & 3.82 \\
\hline 3A3 & 1.17 & 1.12 & -6.22 & -1.48 & -2.70 & -2.40 & 3.82 \\
\hline 3A4 & 0.62 & 0.48 & -5.58 & -1.52 & -3.06 & -2.04 & 3.54 \\
\hline $3 \mathbf{A 5}$ & 0.69 & 0.69 & -5.79 & -1.49 & -3.13 & -1.97 & 3.82 \\
\hline 3A6 & 0.53 & 0.18 & -5.28 & -1.65 & -3.26 & -1.84 & 3.44 \\
\hline 3A7 & 0.74 & 0.27 & -5.37 & -1.61 & -2.99 & -2.11 & 3.26 \\
\hline
\end{tabular}

${ }^{a} E_{\mathrm{red}(\mathrm{DPV})}^{*}$ - observed reduction peak; $E_{\mathrm{Onset}(\mathrm{DPV})}^{\mathrm{red}}=5.1-E_{\mathrm{LUMO}} ; \mathrm{LUMO}=E_{\mathrm{g} \mathrm{opt}}+$ HOMO. 
Table 8 Cytotoxicity of the 3A1-3A7 derivatives expressed as $I C_{50}$ values. The therapeutic index (TI) calculated in ACD/ChemSketch log $P$

\begin{tabular}{|c|c|c|c|c|c|c|}
\hline & $\mathrm{IC}_{50}$ for MCF-7 $[\mu \mathrm{M}]$ & $\mathrm{IC}_{50}$ for PANC- $1[\mu \mathrm{M}]$ & $\mathrm{IC}_{50}$ for $\mathrm{NHDF}[\mu \mathrm{M}]$ & TI for MCF-7 & TI for PANC-1 & $\log P$ \\
\hline 3A1 & $0.48 \pm 0.18$ & $0.29 \pm 0.04$ & $>25$ & $>52.41$ & $>87.11$ & $5.91 \pm 0.64$ \\
\hline 3A2 & $0.87 \pm 0.07$ & $0.37 \pm 0.08$ & $>25$ & $>28.70$ & $>66.84$ & $7.85 \pm 0.64$ \\
\hline 3A4 & $1.07 \pm 0.11$ & $1.87 \pm 0.48$ & $>25$ & $>23.30$ & $>13.40$ & $8.88 \pm 0.66$ \\
\hline $3 \mathbf{A 5}$ & $9.96 \pm 0.24$ & $3.59 \pm 0.78$ & $>25$ & $>2.51$ & $>6.97$ & $11.40 \pm 0.69$ \\
\hline 3A6 & $1.73 \pm 0.12$ & $0.78 \pm 0.19$ & $>25$ & $>14.49$ & $>31.89$ & $8.07 \pm 0.64$ \\
\hline
\end{tabular}

$8.5 \mathrm{~Hz}, 2 \mathrm{H}), 8.03(\mathrm{dd}, J=6.3,5.1 \mathrm{~Hz}, 1 \mathrm{H}), 7.99(\mathrm{~d}, J=8.5 \mathrm{~Hz}$, $2 \mathrm{H}), 7.90(\mathrm{td}, J=7.8,1.7 \mathrm{~Hz}, 2 \mathrm{H}), 7.49(\mathrm{t}, J=7.8 \mathrm{~Hz}, 2 \mathrm{H}), 7.43$ $(\mathrm{d}, J=8.1 \mathrm{~Hz}, 1 \mathrm{H}), 7.41-7.36(\mathrm{~m}, 2 \mathrm{H}), 7.28(\mathrm{~d}, J=7.5 \mathrm{~Hz}, 1 \mathrm{H})$, $4.32(\mathrm{t}, J=7.2 \mathrm{~Hz}, 2 \mathrm{H}), 1.94-1.85(\mathrm{~m}, 2 \mathrm{H}), 1.45-1.30(\mathrm{~m}, 4 \mathrm{H})$, 1.27 (dd, $J=16.7,5.0 \mathrm{~Hz}, 6 \mathrm{H}), 0.87$ (t, $J=6.7 \mathrm{~Hz}, 3 \mathrm{H})$.

${ }^{13} \mathrm{C}$ NMR (126 MHz, DMSO) $\delta 164.99,157.27,155.51,154.46$, 149.03, 148.23, 142.42, 137.84, 137.55, 136.13, 136.06, 133.72, $130.93,129.35,128.56,128.36,125.64,125.59,124.60,124.30$, 121.18, 120.63, 118.92, 118.18, 67.13, 38.21, 29.85, 28.29, 23.36, $22.25,13.73,10.79$.

HRMS (ESI): $m / z$ calcd for $\mathrm{C}_{43} \mathrm{H}_{40} \mathrm{~N}_{7}: 654.3345\left[\mathrm{MH}^{+}\right]$; found 654.3338 .

$3 \mathrm{A6}(27 \mathrm{mg}, 27 \%)$ as a beige solid. ${ }^{1} \mathrm{H}$ NMR $(400 \mathrm{MHz}$, $\left.\mathrm{CDCl}_{3}\right) \delta 8.80(\mathrm{~s}, 2 \mathrm{H}), 8.76(\mathrm{~d}, J=3.9 \mathrm{~Hz}, 2 \mathrm{H}), 8.70(\mathrm{~d}, J=$ $8.0 \mathrm{~Hz}, 2 \mathrm{H}), 8.39(\mathrm{~s}, 1 \mathrm{H}), 8.30(\mathrm{dd}, J=5.5,3.3 \mathrm{~Hz}, 1 \mathrm{H}), 8.11(\mathrm{~d}$, $J=8.6 \mathrm{~Hz}, 2 \mathrm{H}), 8.03-7.97(\mathrm{~m}, 3 \mathrm{H}), 7.96(\mathrm{~s}, 1 \mathrm{H}), 7.94-7.92(\mathrm{~m}$, $1 \mathrm{H}), 7.91(\mathrm{~d}, J=1.7 \mathrm{~Hz}, 1 \mathrm{H}), 7.89(\mathrm{~d}, J=1.8 \mathrm{~Hz}, 1 \mathrm{H}), 7.88-7.86$ (m, 1H), 7.53-7.47 (m, 2H), 7.40-7.36 (m, 2H).

${ }^{13} \mathrm{C}$ NMR $\left(101 \mathrm{MHz}, \mathrm{CDCl}_{3}\right) \delta 156.38,156.16,149.34,148.82$, $148.79,140.04,139.73,139.19,137.57,137.13,136.37,135.56$, $128.95,127.21,126.82,124.76,124.70,124.18,123.41,123.05$, 122.08, 121.58, 120.88, 119.06, 118.85, 117.58 .

HRMS (ESI): $m / z$ calcd for $\mathrm{C}_{35} \mathrm{H}_{23} \mathrm{~N}_{6} \mathrm{~S}: 559.1705\left[\mathrm{MH}^{+}\right]$; found 559.1699.

3A7 (31 mg, 32\%) as a brown solid. ${ }^{1} \mathrm{H}$ NMR $(400 \mathrm{MHz}$, $\left.\mathrm{CDCl}_{3}\right) \delta 8.79(\mathrm{~s}, 2 \mathrm{H}), 8.75(\mathrm{~d}, J=4.0 \mathrm{~Hz}, 2 \mathrm{H}), 8.70(\mathrm{~d}, J=$ $8.0 \mathrm{~Hz}, 2 \mathrm{H}), 8.19(\mathrm{~s}, 1 \mathrm{H}), 8.10(\mathrm{~d}, J=8.6 \mathrm{~Hz}, 2 \mathrm{H}), 7.95(\mathrm{~d}, J=$ $8.6 \mathrm{~Hz}, 2 \mathrm{H}), 7.91(\mathrm{td}, J=7.8,1.7 \mathrm{~Hz}, 2 \mathrm{H}), 7.42(\mathrm{~d}, J=3.7 \mathrm{~Hz}$, $1 \mathrm{H}), 7.38(\mathrm{dd}, J=6.5,4.9 \mathrm{~Hz}, 2 \mathrm{H}), 7.25-7.23(\mathrm{~m}, 2 \mathrm{H}), 7.19(\mathrm{~d}, J$ $=3.7 \mathrm{~Hz}, 1 \mathrm{H}), 7.05(\mathrm{dd}, J=5.0,3.7 \mathrm{~Hz}, 1 \mathrm{H})$.

${ }^{13} \mathrm{C}$ NMR (101 MHz, DMSO) $\delta$ 155.76, 154.82, 149.09, 142.29, 142.10, 137.68, 137.24, 136.91, 136.07, 135.97, 130.88, 128.36, 128.19, 125.48, 124.47, 124.34, 124.30, 124.17, 120.85, 120.62, 118.83 .

HRMS (ESI): $m / z$ calcd for $\mathrm{C}_{31} \mathrm{H}_{20} \mathrm{~N}_{6} \mathrm{~S}_{2}$ : $541.1269\left[\mathrm{MH}^{+}\right]$; found 541.1261.

\subsection{Measurements}

NMR spectra were obtained in deuterated chloroform using Bruker Avance $400 \mathrm{MHz}\left({ }^{1} \mathrm{H}\right.$ and $\left.{ }^{13} \mathrm{C} \mathrm{NMR}\right)$.

High-resolution mass spectrometry (HRMS) measurements were conducted using Mass Spectrometer QTOF (Impact HD, Bruker).
Thermogravimetric analysis (TGA) was carried out using Pyris 1 TGA PerkinElmer.

UV/Vis spectra were obtained using the PerkinElmer Lambda Bio $40 \mathrm{UV} / \mathrm{Vis}$ spectrophotometer at room temperature with a conventional $1.0 \mathrm{~cm}$ quartz cell.

The emission and excitation spectra were obtained using a spectrophotometer (Hitachi F-7000). The quantum yields of fluorescence were determined by the absolute method at room temperature using an integrating sphere with solvent as a blank (FLS980 spectrophotometer). The time-resolved measurement was conducted in optically diluted solutions at room temperature using the time-correlated single photon counting methods via the FLS980 spectrophotometer. The excitation wavelengths were obtained using the picosecond pulsed diode EPLED-275 $\mathrm{nm}$ and $320 \mathrm{~nm}$ with $50 \mathrm{~ns}$ pulse period as light sources. PMT (Hamamatsu, R928P) in cooled housing was used as a detector. The system was leveled at emission wavelengths. In addition, for the analysis of fluorescence decay, an instrument response function was obtained. The IRF contains information about the time response of the overall optical and electronic system. The IRF was designated using the LUDOX solution as a standard at 275 and $320 \mathrm{~nm}$.

Electrochemical measurements were conducted using the PARSTAT 2273 potentiostat - galvanostat. The sample was dissolved in a chloroform solution with tetrabutylammonium hexafluorophosphate $\mathrm{Bu}_{4} \mathrm{NPF}_{6}$ (Sigma Aldrich, 99\%). All solutions were freshly prepared and purged with argon bubbling for 30 minutes. The measurements were conducted in a three-electrode cell with a $2.0 \mathrm{~mL}$ volume of the sample solution.

\subsection{Cell culture}

The human breast carcinoma (MCF-7) cells were obtained from ATCC, human Caucasian pancreas (PANC-1) cells were obtained from ECACC, and the normal human fibroblasts (NHDF) were obtained from PromoCell. Cells were grown as monolayer cultures in Dulbecco's modified Eagle's medium with the antibiotic gentamicin $\left(200 \mu \mathrm{L} / 100 \mathrm{~mL}\right.$ medium) in $75 \mathrm{~cm}^{2}$ flasks (Nunc). DMEMs for MCF-7 and PANC-1 were supplemented with 12\% heat-inactivated fetal bovine serum (Sigma) and for NHDF with 15\% non-inactivated fetal bovine serum (Sigma). Cells were cultured under standard conditions at $37{ }^{\circ} \mathrm{C}$ under a humidified atmosphere at $5 \% \mathrm{CO}_{2}$. 


\subsection{Cytotoxicity studies}

The cells were seeded in 96-well plates (Nunc) at the density of 5000 cells/well (MCF-7 and PANC-1) and 4000 cells/well (NHDF) and incubated at $37^{\circ} \mathrm{C}$ for $24 \mathrm{~h}$. The assay was performed following a $72 \mathrm{~h}$ incubation with varying concentrations of the compounds that were being tested. Then, $20 \mu \mathrm{L}$ of CellTiter 96®AQueous One Solution-MTS (Promega) was added to each well (with $100 \mu \mathrm{L}$ DMEM without phenol red) followed by incubation for further $1 \mathrm{~h}$ at $37^{\circ} \mathrm{C}$. The optical densities of the samples were analyzed at $490 \mathrm{~nm}$ using a multi-plate reader (Synergy 4, Bio Tek). The results were expressed as a percentage of the control and calculated as the inhibitory concentration ( $\mathrm{IC}_{50}$ ) values (using GraphPad Prism 7). Each individual compound was tested in triplicate in a single experiment with each experiment being repeated three or four times.

\section{Conclusions}

Herein, we presented a synthesis method and comprehensive characterization of the derivatives 3A1-3A7 of $4^{\prime}$-(1,2,3-triazol-4-yl)phenyl-2,2' $: 6^{\prime}, 2^{\prime \prime}$-terpyridine with various (hetero) aryl substituents. All compounds were obtained by $\mathrm{Cu}(\mathrm{I})$ catalysed 1,3-dipolar cycloaddition reactions with yields between 21 and $42 \%$. The target compounds have high thermal stability with a temperature of $5 \%$ sample weight loss above $315{ }^{\circ} \mathrm{C}$. The compounds 3A1-3A7 have displayed almost identical absorption maxima (274-278 $\mathrm{nm}$ ) with an exception for 3A7 that exhibits an additional band at $330 \mathrm{~nm}$. All the obtained compounds exhibit fluorescence in the range of 360-442 $\mathrm{nm}$ with quantum yields in the range of $7-41 \%$ and effective lifetime values in the range from 0.41 to $4.21 \mathrm{~ns}$. From the electrochemical point of view, 3A6 with the dibenzothiophene substituent has lowest oxidation potential, similar to $\mathbf{3 A 7}$ that contains the 2,2'-bithiophene unit. Derivatives with the phenyl or pyridine ring undergo oxidation at highest potentials. The observed differences are in agreement with the results of the theoretical calculations, which show disparities of contribution in the creation of particular orbitals. Moreover, the preliminary tests of the anticancer activity of the described terpyridine derivatives 3A1-3A7 conducted on two cancer cell lines, i.e. breast (MCF7) and pancreatic (PANC-1), show that the group of studied compounds also has medicinal value, with comparable $\mathrm{IC}_{50}$ values. The most active derivative proved to be $\mathbf{3 A 3}$ on the PANC-1 cells $\left(\mathrm{IC}_{50}=0.114 \mu \mathrm{M}\right)$ with lowest lipophilicity. The results showed that the examined compounds exhibited interesting optical as well as biological properties. Thus, this can indicate their application as potential materials in organic electronics as well as medicine, and this will be the subject of our future investigations.

\section{Conflicts of interest}

There are no conflicts to declare.

\section{Acknowledgements}

This work was supported by the Ministry of Science and Higher Education, Poland (Diamentowy Grant number 0215/ DIA/2015/44 (D. Z.)) and the National Science Centre of Poland Projects: ETIUDA 6 2018/28/T/ST5/00005 (D. Z.); PRELUDIUM 12 2016/23/N/NZ7/00351 (K. M.). Calculations have been carried out using resources provided by Wroclaw Centre for Networking and Supercomputing (http://wcss.pl), grant no. 18.

\section{Notes and references}

1 A. Wild, A. Winter, F. Schlütter and U. S. Schubert, Chem. Soc. Rev., 2011, 40, 1459-1511.

2 C.-F. Zhang, H.-X. Huang, B. Liu, M. Chen and D.-J. Qian, J. Lumin., 2008, 128, 469-475.

3 D. Saccone, C. Magistris, N. Barbero, P. Quagliotto, C. Barolo and G. Viscardi, Materials, 2016, 9, 137.

4 D. Zych, A. Slodek, M. Matussek, M. Filapek, G. SzafraniecGorol, S. Maślanka, S. Krompiec, S. Kotowicz, E. SchabBalcerzak, K. Smolarek, S. Maćkowski, M. Olejnik and W. Danikiewicz, Dyes Pigm., 2017, 146, 331-343.

5 R. Lakshmanan, N. C. Shivaprakash and S. S. Nair, J. Lumin., 2015, 168, 145-150.

6 E. I. Ikitimur-Armutak, K. Sonmez, K. Akgun-Dar, G. Sennazli, A. Kapucu, F. Yigit, V. T. Yilmaz and E. Ulukaya, Anticancer Res., 2015, 35, 1491-1497.

7 A. M. Arundhoti Mandal, A. Maity, S. Bag, P. Bhattacharya, A. K. Das and A. Basak, RSC Adv., 2017, 7, 7163-7169.

8 A. Winter, G. R. Newkome and U. S. Schubert, ChemCatChem, 2011, 3, 1384-1406.

9 H. Hofmeier and U. S. Schubert, Chem. Soc. Rev., 2004, 33, 373-399.

10 A. Mishra, E. Mena-Osteritz and P. Bäuerle, Beilstein J. Org. Chem., 2013, 9, 866-876.

11 S. S. M. Fernandes, M. Belsley, C. Ciarrocchi, M. Licchelli, M. Manuela and M. Raposo, Dyes Pigm., 2018, 150, 49-58.

12 A. Baschieri, L. Sambri, I. Gualandi, D. Tonelli, F. Monti, A. D. Esposti and N. Armaroli, RSC Adv., 2013, 3, 6507.

13 S. Zhang, Z. Xu, C. Gao, Q.-C. Ren, L. Chang, Z.-S. Lv and L.-S. Feng, Eur. J. Med. Chem., 2017, 138, 501-513.

14 P. López-Rojas, M. Janeczko, K. Kubiński, Á. Amesty, M. Masłyk and A. Estévez-Braun, Molecules, 2018, 23, 199.

15 M. H. Shaikh, D. D. Subhedar, L. Nawale, D. Sarkar, F. A. Kalam Khan, J. N. Sangshetti and B. B. Shingate, MedChemComm, 2015, 6, 1104-1116.

16 K. Wechakorn, S. Prabpai, K. Suksen, P. Kanjanasirirat, Y. Pewkliang, S. Borwornpinyo and P. Kongsaeree, Luminescence, 2018, 33, 64-70.

17 B. Rathinam, C.-C. Chien, B.-C. Chen and J.-H. Liu, Tetrahedron, 2013, 69, 235-241.

18 H. C. Kolb and K. B. Sharpless, Drug Discovery Today, 2003, 8, 1128-1137.

19 M. S. Singh, S. Chowdhury and S. Koley, Tetrahedron, 2016, 72, 5257-5283. 
20 N. V. Sokolova and V. G. Nenajdenko, RSC Adv., 2013, 3, 16212.

21 D. Zych, A. Slodek, S. Krompiec, K. Malarz, A. MrozekWilczkiewicz and R. Musiol, ChemistrySelect, 2018, 3, 70097017.

22 A. Herner, I. Nikić, M. Kállay, E. A. Lemke and P. Kele, Org. Biomol. Chem., 2013, 11, 3297.

23 W. Zhu and D. Ma, Chem. Commun., 2004, 888.

24 C. H. Devillers, S. Hebié, D. Lucas, H. Cattey, S. Clément and S. Richeter, J. Org. Chem., 2014, 79, 6424-6434.

25 M. Frisch, G. Trucks, H. Schlegel, G. Scuseria, M. Robb, J. Cheeseman, G. Scalmani, V. Barone, B. Mennucci, G. Petersson, H. Nakatsuji, M. Caricato, X. Li, H. Hratchian, A. Izmaylov, J. Bloino, G. Zheng, J. Sonnenberg, M. Hada, M. Ehara, K. Toyota, R. Fukuda, J. Hasegawa, M. Ishida, T. Nakajima, Y. Honda, O. Kitao, H. Nakai, T. Vreven, J. Montgomery, J. Peralta, F. Ogliaro,
M. Bearpark, J. Heyd, E. Brothers, K. Kudin, V. Staroverov, R. Kobayashi, J. Normand, K. Raghavachari, A. Rendell, J. Burant, S. Iyengar, J. Tomasi, M. Cossi, N. Rega, J. Millam, M. Klene, J. Knox, J. Cross, V. Bakken, C. Adamo, J. Jaramillo, R. Gomperts, R. Stratmann, O. Yazyev, A. Austin, R. Cammi, C. Pomelli, J. Ochterski, R. Martin, K. Morokuma, V. Zakrzewski, G. Voth, P. Salvador, J. Dannenberg, S. Dapprich, A. Daniels, Ö. Farkas, J. Foresman, J. Ortiz, J. Cioslowski and D. Fox, Gaussian 09, Revis. B.01, Gaussian, Inc., Wallingford CT.

26 J. Tomasi, B. Mennucci and R. Cammi, Chem. Rev., 2005, 105, 2999-3094.

27 P. Bujak, I. Kulszewicz-Bajer, M. Zagorska, V. Maurel, I. Wielgus and A. Pron, Chem. Soc. Rev., 2013, 42, 8895.

28 N. Elgrishi, M. B. Chambers, V. Artero and M. Fontecave, Phys. Chem. Chem. Phys., 2014, 16, 13635-13644.

29 L. Persaud and G. Barbiero, Can. J. Chem., 1991, 69, 315-321. 